\title{
Factors Influencing Social Media in Managing Corporate Reputation for a Christian Organisation in Developing Countries Based on the VT4 Model
}

\author{
Dexter Adamson Njuka ${ }^{*}$, Jackson Phiri ${ }^{2}$ \\ ${ }^{1}$ Graduate School of Business, University of Zambia, Lusaka, Zambia \\ ${ }^{2}$ School of Natural Sciences, Department of Computer Sciences, University of Zambia, Lusaka, Zambia \\ Email: ^dextertambulukani@gmail.com, jackson.phiri@cs.unza.zm
}

How to cite this paper: Njuka, D. A., \& Phiri, J. (2021). Factors Influencing Social Media in Managing Corporate Reputation for a Christian Organisation in Developing Countries Based on the VT4 Model. Technology and Investment, 12, 66-81. https://doi.org/10.4236/ti.2021.122005

Received: January 22, 2021

Accepted: May 8, 2021

Published: May 11, 2021

Copyright $\odot 2021$ by author(s) and Scientific Research Publishing Inc. This work is licensed under the Creative Commons Attribution International License (CC BY 4.0).

http://creativecommons.org/licenses/by/4.0/

(c) (i) Open Access

\begin{abstract}
Social media has changed the dynamics of communication and it has become the present truth mantra for information exchange. Social media has in quick succession grown exponentially to reach out to millions of masses than traditional communication media. The question no longer borders on the need for the organization to use social media but on the dynamics of how to establish an online reputation. Management of corporate reputation for organizations on social media cannot fully be effective without establishing influencing factors. Hence, the two objectives of this study were to establish factors influencing social media in managing corporate reputation for Christian organizations and at the same time to establish whether there is any relationship among these factors. A descriptive and survey design was adopted for the study. The population for this study consisted of church members and leaders of the Seventh-day Adventist Church from the three provinces namely, Lusaka, Central ad Copperbelt with a total membership of 608,357. A questionnaire was used in drawing information from respondents, which contained five sections. Two research questions and nine hypotheses were formulated and tested. The data collected was analyzed using Statistical Package for Social Sciences (SPSS version 24.0), for frequency distribution. Further analysis was carried out using linear regression and correlation analysis. From the findings made in the study, there is a significant role played by social media in managing corporate reputation for Christian organizations. It was recommended that management should be more conscious of the factors that influence social media in reputation management, as well as to improve on their inadequacies and address its organizational threats promptly. Further, managers should strive to focus on having a peculiar online presence in line
\end{abstract}


with their given organizational reputation.

\section{Keywords}

Social Network Sites, Reputation Management, Corporate Reputation, Brand Ambassador, VT4 Theory, Christian Organization, Seventh-Day Adventist Church, Leadership

\section{Introduction}

Social media has changed the dynamics of communication and has become the present truth mantra for information exchange (Kaul et al., 2015). Social media has in quick succession grown exponentially, reaching a lot to millions of masses much faster compared to the traditional communication media. The question no longer borders on the need for the organization to be on social media but on the dynamics of how to enhance its presence there. With the free flow of information on social media, the risk of reputation management has become more susceptible than it has ever been on traditional media of communication (Jones et al., 2009). The corporate reputation management of an organization impacts how the organization is perceived by both internal and external stakeholders who make the business decisions of the organization relying on the information trending. The corporate reputation phenomenon cuts across all kinds of organizations.

For instance, the faith-based organization that is not proactive to its social media risks a major corporate reputation crisis, which can result in the reduction of the number of its membership. The Seventh-day Adventist church is a faith-based organization in Zambia whose administrative offices called Conferences or Fields exist almost in every province of Zambia except for Muchinga Province. These conferences are administered by two national entities, which are called Northern Zambia Union Conference and Southern Zambia Union, which subscribe to the administration office in southern Africa called Southern Africa-Indian Ocean Division, which also subscribes to the General Conference of the Seventh-day Adventists in the world. This research was done in three provinces namely, Lusaka Province, Central Province, and Copperbelt Provinces. The three provinces had a total baptized membership of 608,357 from 2810 congregations at the time of the research.

\section{Statement of the Problem}

There is a problem with Zambia Christian Originations in appreciating the influence of social media in managing corporate reputation as evidenced week in and week out from social media postings that continue to reveal alleged misdeeds be it moral or financial massed on the many Christian organizations. It is argued that despite the formulation of three church mother bodies in Zambia and a ministry of religious affairs, there remains no deliberate social media strategy on how to manage or handle corporate reputation for these Christian organi- 
zations. There remains a need for a model that depicts the elements of social media management that could be used to describe mechanisms and processes by which these faiths' reputations can be influenced by social media. For lack of a well-established reputation management system in these organizations, there has been a growing trend among the citizens to become indifferent towards religious matters Needless to mention, that this can perpetuate moral decadency in the country, which in the end leads to economic laggardness. Rumors of sexual and moral scandals among the clergy that have continued to do rounds especially on social media and without a robust counter from the establishment could be stalled before they could severely damage the organization's reputation had there been an ideal Reputation Management model for religious groupings. Perhaps a study, which could outline the reasons for the elicited performances required.

Thus, this research seeks to establish factors influencing social media in managing corporate reputation for a Christian organization of developing countries and if there is any relationship among them. The findings of this study will resonate with the benefits of the corporate world in that social media plays an influential role in corporate reputation management. Also, this will in turn help organizations to derive from this study recommendation on how they can effectively manage their reputation online

\section{Literature Review}

\subsection{Social Media in Managing Corporate Reputation}

Social Media (SM) continues to be seen as a trailblazer phenomenon of information technology and will continue to be so in many years to come. In all essence, Social media is not a technology in itself but represents a process more than that. The development of Web 2.0 helped shape the birth of Social media. (Kim et al., 2009) posits that word Web 2.0 was coined by (O'Reilly, 2007) to explain the process of technological and social trends that were happening via Internet. Examples of these are blogs, Wikipedia and online network sites. Needless to mention as stated by (Hoegg et al., 2006), he agrees that these technological advancements helped shape social trends. It is almost impossible to define social media as an infant of the pioneering information technology platforms such as email and chartrooms, (Kane et al., 2014). There lays many similarities between these platforms and social media.

As argued by (Kang \& Sung, 2017), social media "is a set of affordances supported by a diverse and evolving technological infrastructure that enables people to communicate and collaborate in novel ways." As well as these affordances reinvent, social media platforms will continue to embrace new technologies so as to enhance online activism in knowledge exchange and generation. From yesteryears, social media is proving to be a mantra as a cost effective reputation management tool for organizations. Different from the traditional channels, social media gives an instantaneous interaction and feedback between the organization and its stakeholders. 


\subsection{Definition of Online Corporate Reputation}

(Pfarrer et al., 2010) defines reputation as an "impression of public esteem or high regard judged by others". Corporate reputation is a trait or a character of a given organization as seen, weather as good or as not good by the stakeholders it subscribes to. When its image is viewed as credible and clear by the said constituency, the organization is said to have a good reputation. Other scholars define corporate reputation as "the process of positioning, monitoring, measuring, talking, and listening as the organization engages in a transparent and ethical dialogue with its various online stakeholders" (Jones et al., 2009). Therefore management of online reputation can be said to be a deliberate online involvement with individuals, sharing content, aggregating the posts of stakeholders, keeping a record of their views and dealing with online complaints and revisiting suggestions that were given by stakeholders online.

Social Identity Theory posits that humans try to uphold or enhance their self-esteem through ties with a certain social cluster of individuals who have similarities same goals and traits. The same can be said about both internal and external organizational stakeholders that they love to associate with an organization basing on its ideal identity and attributes. This entails that different individuals do have varying reasons for associating with a particular organization. Organizations should therefore manage corporate reputation as a whole less mindful of the distinct differences (van der Merwe \& Puth, 2014).

\subsection{Benefits of Good Corporate Reputation}

(Deephouse et al., 2016) posits that as much as corporate reputation is deemed as an intangible asset for the business of the organization, it plays a pivotal role in business how is conducted, recruitment policy, and other stakeholders' interests. According to (Mousavi \& Vahdati, 2015) well-managed corporate reputation can result in trustworthy and thereby leveraging cash dividends and high profit turn out because of the enhanced stakeholder positive perception of the organization. It goes without refuting that much scholarly work has been done to prove that well managed corporate reputation influences stakeholder service interests. Also an organization that has a well-managed reputation is seen in the stakeholders' eye as a socially responsible one and this will lead to a network of referrals for more business.

(Kim \& Ferguson, 2019) quotes (Fombrun \& Riel, 2003) to state that corporate reputation has gained ground in public relations because "it is a key source of distinctiveness that produces support for the company and differentiates it from rivals." It is further stated that corporate reputation is considered as one of the major factors that influences organizations to match up to the business rivals. Stakeholders look at an organization's reputation as a guarantee of its reliability to corporate governance. It goes without saying that a positive organizational reputation is both in definite and indefinite ways. For instance it produces great attitude, reliable support and royalty from clients and it attracts reputable employees because people love to associate with a good name. 


\subsection{Internal Communication Matrix}

(Al-Alawi et al., 2007) point that communication plays a pivotal role in the conditions for human survival. Mankind has always been a social being from the beginning so communication has been and will always remain key to humanity, as its main objective is to promote societal communion. In view of this, Communication therefore creates a platform for man to share ideas, knowledge, experiences, opinions and other information that is relevant to human life. (Kang \& Sung, 2017) argue that if internal policies do not meet the employee's anticipations, the employees become vocal in an organization. Employees therefore, are the most critical stakeholders because they are the strongest supporters and the most vocal critics if their anticipations are not met (Waters et al., 2009).

\subsection{Employees as Online Brand Ambassadors}

(Madsen \& Verhoeven, 2019) argues that social media has ensued the phenomena of employees being considered as brand ambassadors. This foretells of a thin line being drawn between what they do in privacy and in public as far as the organization is concerned. As things stand there is too much expectations from the employers on how they relate on social media. Employers are to endeavor to protect their brands online as much as they manage their employees as the organization's ambassadors. This task is seemingly to be the new type of workplace watchdog. Social media has become a very important part of day-to-day communication for organizational employees, as there is a demand for integration of messages as well as expansion of its existence in managing corporate reputation. Arguably, the more the employees use social media, the more they make the organization more visible. But then using social media as workplace surveillance has its own consequences such as making organization's private issues become public. Polity and power tensions become potential to shift away from the organizational core business. Needless to mention that if well managed, workplace social media watchdog can create more a conducive workplace.

\subsection{Gaining Organization's CSR Reputation on Social Media}

(Abitol \& Lee, 2015) posit that it is important to realize that having a communication strategy via social media has great potential of making the company become more visible, which has a great impact on building an organization's corporate social responsibility. No wonder Impression management theory gives reasons as to why there is motivation for stakeholders to express social media actions such as liking, sharing, following, sharing or commenting. Impression theory is defined as "the process by which individuals attempt to control the impressions others form of them," Consumers can aggregate impressions others have of them on social media by deliberately associating or subscribing to just causes by following or sharing an organization's CSR page with them. For instance, a CSR topic posted on Facebook has the potential of increasing chances of making the public to follow and like the page. As soon as an individual shares 
a post it will appear on his or her friends' feed, which in turn makes that person's visibility increase simultaneously with that of the organization. The organization visibility in association with CSR postings makes it become perceived positively by the public on the subject matter.

\section{Methodology}

This research was necessitated by the Agenda Setting Theory that traditional media has from time in the past used to influence the importance placed on topics to the public agenda. (Mcombs \& Shaw, 1972) for example when an item is featured frequently and prominently, the public tend to take that issue as of most importance. Unfortunately its emphasis is on content and not influence. With (Shoemaker \& Reese, 1996) Hierarchy of Influence on Media content theory, as guided by a section of scholars, it was appropriate for the purpose of this research to use the VT4 of organization content theory.

Reputation management creates a feedback platform for organization leadership to realize what their stakeholder's perception about them is about. Using social media analysis can help the organization to realign its strategic approach with the expectations of the stakeholders. The five reputational dimensions here mentioned, as prominence, public esteem, properties, plexes and positioning are the kind of feedback that provide organizations with reputational feedback. These media saliences form what is know as VT4 framework of social media salience. VT4 stands for volume, tone, topics, ties, and timing, The VT4 is a theoretical model that states that these five Social Media saliences (prominence) can influence the overall score of corporate reputation management (Carroll, 2014). The model is presented in Figure 1.

\subsection{Research Design and Population Sampling Technique}

A quantitative method was used with a survey as the methodology in order to gather research material in structured questionnaire. The questionnaire was derived from variables of the structured VT4 conceptual framework so as to validate the hypothesis. This research focused on the Seventh-day church membership of 608,357 from three different provinces. The targeted respondents were

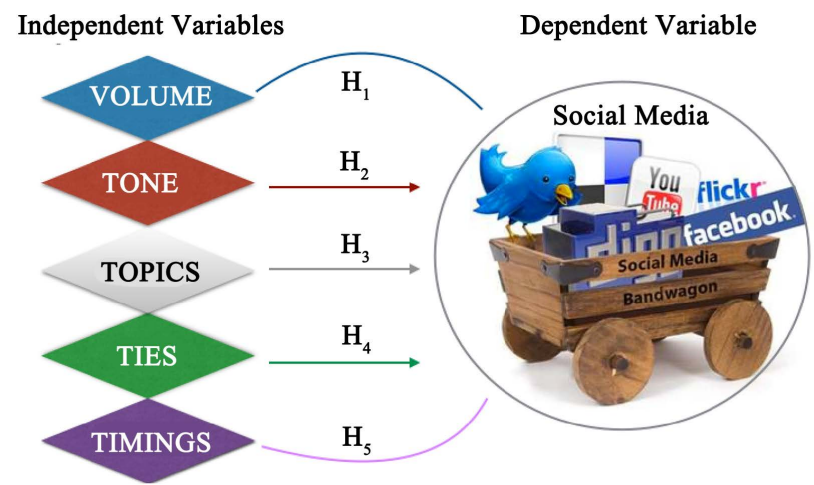

Figure 1. VT4 model. 
500 and 381 responded and returned the questionnaires representing $76.2 \%$. Using an online sample size calculator by qualtrics.com, this response rate was deemed overwhelming for the analysis. Needless to state the sample of this survey is a representation of the total membership from Lusaka, Central and Copperbelt provinces. Questionnaires were distributed to an average of two congregations per district and the respondents were randomly selected.

\subsection{Data Collection Methods}

Data was gathered from each answered questionnaire. This instrument was selfadministered printed document so as for the researcher to maximize the distribution and return rate. Needless to state some of the scholars who have posited the advantages of using a questionnaire as a data collection tool from uniform response to efficiency when it comes to interpreting the data therein (Mashall, 2005). There was high level of confidentiality as there was no provision for respondents to state their personal particulars. The instrument was structured with only closed-ended questions. A 5-point Likert type scale questions were used to get answers differing degrees from one extreme to the other. Raw data was stored in Microsoft excel/spreadsheet in preparation for the process in the next chapter.

\section{Results and Discussion}

\section{Hypothesis 1:}

H1: Content Volume has a significant influence on Social Media's contribution to organization reputation management.

$\mathrm{H}_{0}$ : Content Volume's influence on Social Media is insignificant.

The table and graphs follow present social media as a dependent variable and content volume, content tone, content topics, content ties and content timing as independent variables. For this research, social media comprises of the five main media as WhatsApp, Facebook, WeChat, Twitter and Instagram as dependent variables.

Table 1 presents three statistical tests (Phi coefficient, Cramer's V and ChiSquare tests). The Chi-Square test statistic used is the significance value (the $p$ value). This statistic gives the result that shows whether there is a statistically significant association between the variables. Cramer's V and Phi coefficients provide symmetric measures that test the association or correlation between two variables and the strength of that association respectively. The findings have been segmented to show the various social media applications that form the dependent variables and their individual relationship with the VT4 model. These variables are detailed further according to the VT4 framework.

Most of the findings above are statistically significant $(p=0.000)$, but the Phi Coefficients are quite high as shown suggesting that there is only a negligible association between variables as explained below. The values below are aggregates of all the variable values for the content volume. 
Table 1. Signifant correlation between variables.

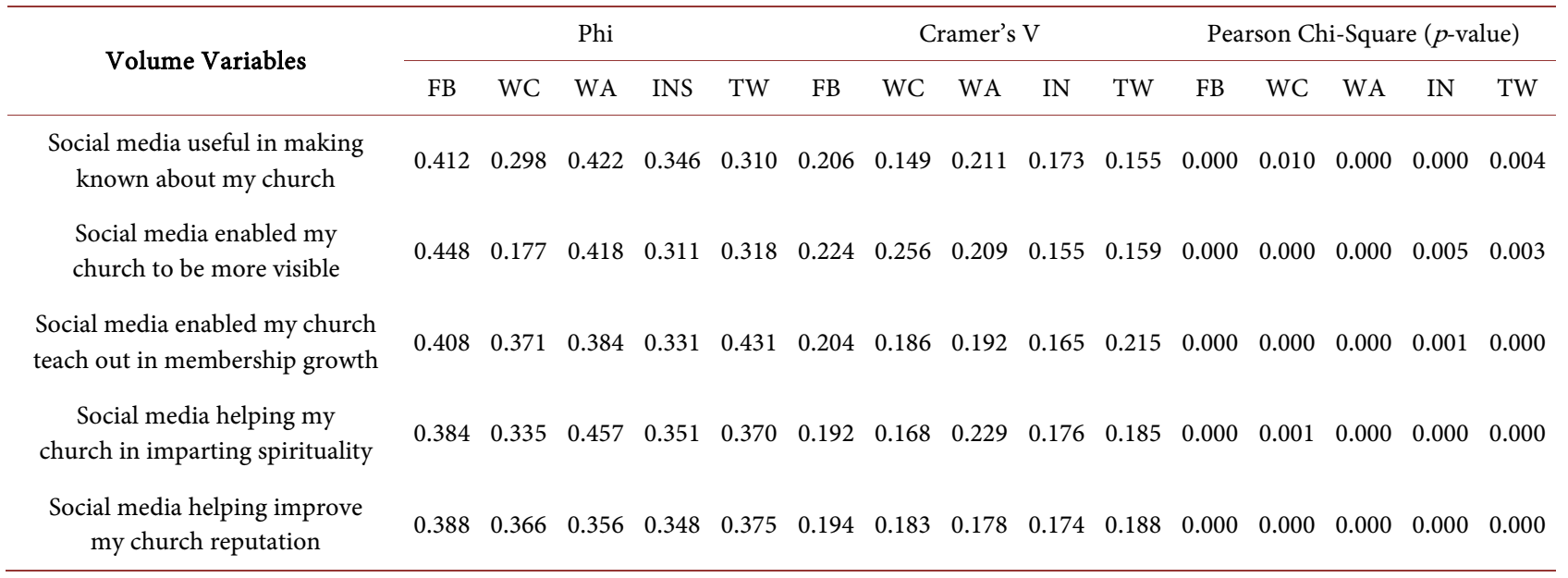

\section{Facebook}

$p=0.000$

Phi $=0.408$

Cramer's V $=0.204$

The $p$-value $(0.000)$, less than 0.05 is statistically significant and therefore shows that there is a statistically significant association between Facebook as a social media platform and the volume in the VT4 model. Cramer's V (0.204) represents a strong association or correlation between the two variables also. The Phi coefficient (0.408) that shows the strength of this relationship signifies that the relationship between social media (Facebook) and content volume is a strong one as shown in Table 2 on interpretation of phi coefficients.

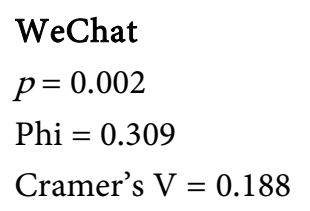

The $p$-value (0.002), less than 0.05 is statistically significant and therefore shows that there is a statistically significant association between WeChat as a social media platform and the content volume in the VT4 model. Cramer's V $(0.188)$ represents a strong association or correlation between two variables also. The Phi coefficient (0.309) that shows the strength of this relationship signifies that the relationship between social media (WeChat) and content volume is a moderate positive relationship as shown in Table 2 on interpretation of phi coefficients.

\section{WhatsApp}

$$
\begin{aligned}
& p=0.000 \\
& \text { Phi }=0.407
\end{aligned}
$$

Cramer's V $=0.204$

The $p$-value $(0.000)$, less than 0.05 is statistically significant and therefore shows that there is a statistically significant association between social media (WhatsApp) platform and the content volume in the VT4 model. Cramer's V 
Table 2. Interpretation of phi coefficient.

\begin{tabular}{cccc}
\hline Phi Value & Relationship strength & Phi Value & Relationship strength \\
\hline+0.70 or higher & $\begin{array}{c}\text { Very strong } \\
\text { positive relationship }\end{array}$ & -0.70 or higher & $\begin{array}{c}\text { Very strong negative } \\
\text { relationship }\end{array}$ \\
+0.40 to +0.69 & $\begin{array}{c}\text { Strong positive } \\
\text { relationship }\end{array}$ & -0.40 to -0.69 & $\begin{array}{c}\text { Strong negative } \\
\text { relationship }\end{array}$ \\
+0.30 to +0.39 & $\begin{array}{c}\text { Moderate positive } \\
\text { relationship }\end{array}$ & -0.30 to -0.39 & $\begin{array}{c}\text { Moderate negative } \\
\text { relationship }\end{array}$ \\
+0.20 to +0.29 & $\begin{array}{c}\text { weak positive } \\
\text { relationship }\end{array}$ & -0.20 to -0.29 & $\begin{array}{c}\text { weak negative } \\
\text { relationship }\end{array}$ \\
+0.01 to +0.19 & $\begin{array}{c}\text { No or negligible } \\
\text { relationship }\end{array}$ & -0.01 to -0.19 & $\begin{array}{c}\text { No or negligible } \\
\text { relationship }\end{array}$ \\
0 & No relationship & 0 & No relationship \\
\hline
\end{tabular}

Table 3. Cramer's V interpretation.

\begin{tabular}{cc}
\hline Cramer's V & Interpretation \\
\hline$>0.25$ & Very strong \\
$>0.15$ & Strong \\
$>0.10$ & Moderate \\
$>0.05$ & Weak \\
$>0.0$ & No or very weak \\
\hline
\end{tabular}

Source: Quinnipiac university (online).

(0.204) represents a strong association or correlation between the social media dependent variable and content volume attributes as independent variables. The Phi coefficient (0.407) that shows the strength of this relationship signifies that the relationship between social media (WhatsApp) and content volume is a strong positive relationship as shown in Table 2 on interpretation of phi coefficients.

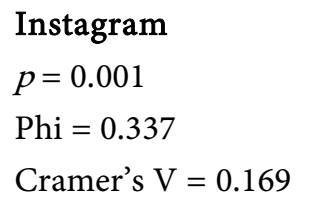

The $p$-value (0.001), less than 0.05 is statistically significant and therefore shows that there is a statistically significant association between social media (Instagram) platform and the content volume in the VT4 model. Cramer's V (0.169) represents a strong association or correlation between the social media (Instagram) dependent variable and content volume attributes as independent variables. The Phi coefficient (0.337) that shows the strength of this relationship signifies that the relationship between social media (Instagram) and content volume is a moderate positive relationship as shown in Table 2 on interpretation of phi coefficients.

\section{Twitter}

$$
p=0.001
$$


Phi $=0.361$

Cramer's V $=0.180$

The $p$-value $(0.001)$, less than 0.05 is statistically significant and therefore shows that there is a statistically significant association between social media (twitter) platform and the content volume in the VT4 model. Cramer's V (0.180) represents a strong association or correlation between the social media (Instagram) dependent variable and content volume attributes as independent variables. The Phi coefficient (0.361) that shows the strength of this relationship signifies that the relationship between social media (twitter) and content volume is a moderate positive relationship as shown in Table 2 on interpretation of phi coefficients.

Figure 2 and Table 1 present a summary of the relationship between social media platforms and content volume from the VT4 model. As seen in the table and figure, all five social media platforms show a statistically significant association with the content volume variables. The strength of this association has been observed to be different by the Phi coefficient and Cramer's V coefficient which have shown that the degree of association for the social media platforms with content volume is not the same. The relationship represents a ranking of the media platforms in terms of how the various factors in content volume enable social media to contribute towards the management of corporate reputation are ranked in the order Facebook, Instagram, WhatsApp, WeChat and Twitter in the last position. Furthermore, the hypotheses may be summarized as follows:

$\mathrm{H}_{1}$ : Content Volume has a significant influence on Social Media's contribution to organization reputation management $p$-value found to be less than 0.05 , hence supported.

$\mathrm{H}_{10}$ : Content Volume's influence on Social Media is insignificant. Null hypothesis is hence rejected.

\section{Hypothesis 2:}

$\mathrm{H} 2$ : Content Tones has a significant influence on Social Media's contribution to organization reputation management.

$\mathrm{H} 2_{0}$ : Content Tone's influence on Social Media is insignificant.

Social Media and Content Volume

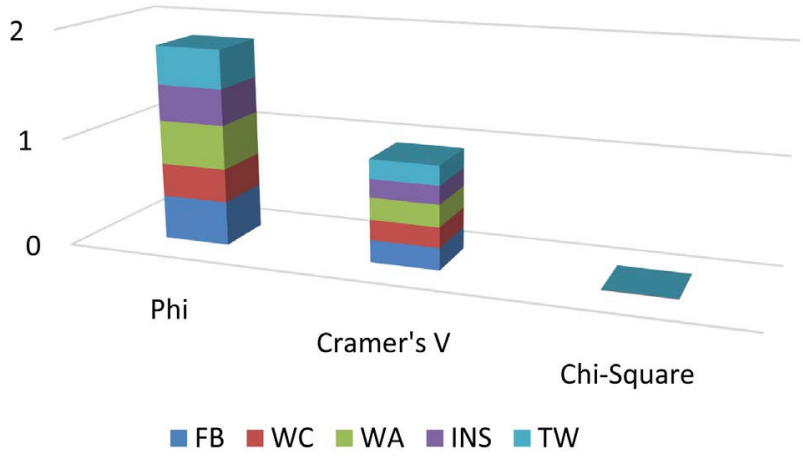

Figure 2. Relationship between social media and content volume. 
Table 4 presents a summary of the relationship between social media platforms and content tone from the VT4 model. As seen in the table and figure, all the five social media platforms show a statistically significant association with the content tone variables. The strength of this association has been observed to be different by the Phi coefficient and Cramer's V coefficient which has shown that the degree of association for the social media platforms with content tone is not the same. The relationship represents a ranking of the media platforms in terms of how they contribute towards the content tone ranked in the order Facebook, Instagram, WhatsApp, WeChat and Twitter in the last position. The second hypotheses may be summarized as follows:

H2: Content Tone has a significant influence on Social Media's contribution to organization reputation management $p$-value found to be less than 0.05 , hence supported.

$\mathrm{H} 2_{0}$ : Content Tone's influence on Social Media is insignificant. Null hypothesis is hence rejected.

\section{Hypothesis 3:}

H3: Content Topics has a significant influence on Social Media's contribution to organization reputation management.

$\mathrm{H} 3_{0}$ : Content Topic's influence on Social Media is insignificant.

Table 5 presents a summary of the relationship between social media platforms and content topics from the VT4 model. As seen in the table and figure, all five social media platforms show a statistically significant association with the content tone variables. The strength of this association has been observed to be different by the Phi coefficient and Cramer's V coefficient which has shown that the degree of association for the social media platforms with content topics is not the same. The relationship represents a ranking of the media platforms in terms of how they contribute towards the content topics ranked in the order Facebook, Instagram, WhatsApp, WeChat and Twitter in the last position.

\section{Hypothesis 4:}

H4: Content Ties has a significant influence on Social Media's contribution to organization reputation management.

Table 4. Content tone statistics with social media.

\begin{tabular}{|c|c|c|c|c|c|c|c|c|c|c|c|c|c|c|c|}
\hline \multirow{2}{*}{ Tone Vari } & \multicolumn{5}{|c|}{ Phi } & \multicolumn{5}{|c|}{ Cramer's V } & \multicolumn{5}{|c|}{ Pearson Chi-Square ( $p$-value) } \\
\hline & $\mathrm{FB}$ & WC & WA & INS & TW & FB & WC & WA & INS & TW & FB & WC & WA & INS & TW \\
\hline Averages & 0.436 & 0.374 & 0.347 & 0.350 & 0.343 & 0.218 & 0.187 & 0.173 & 0.175 & 0.170 & 0.000 & 0.000 & 0.001 & 0.026 & 0.020 \\
\hline
\end{tabular}

Table 5. Content topics statistics with social media.

\begin{tabular}{|c|c|c|c|c|c|c|c|c|c|c|c|c|c|c|c|}
\hline \multirow{2}{*}{ Topics Var } & \multicolumn{5}{|c|}{ Phi } & \multicolumn{5}{|c|}{ Cramer's V } & \multicolumn{5}{|c|}{ Pearson Chi-Square ( $p$-value) } \\
\hline & FB & WC & WA & INS & TW & FB & WC & WA & IN & TW & $\mathrm{FB}$ & WC & WA & INS & TW \\
\hline Averages & 0.526 & 0.465 & 0.404 & 0.438 & 0.462 & 0.263 & 0.232 & 0.202 & 0.219 & 0.231 & 0.000 & 0.000 & 0.000 & 0.000 & 0.000 \\
\hline
\end{tabular}


$\mathrm{H} 4_{0}$ : Content Ties's influence on Social Media is insignificant.

Table 6 presents three statistical tests (Phi coefficient, Cramer's V and ChiSquare tests). The Chi-Square test statistic used is the significance value (the $p$ value). This statistic gives the result that shows whether there is a statistically significant association between the variables of the content ties and social media in its role in corporate reputation management. Cramer's V and Phi coefficients provide symmetric measures that test the association or correlation between two variables and the strength of that association respectively. The findings have been segmented to show the various social media applications that form the dependent variables and null hypothesis is hence rejected.

\section{Hypothesis 5:}

H5: Content Timing has a significant influence on Social Media's contribution to organization reputation management.

$\mathrm{H}_{5}$ : Content Timing's influence on Social Media is insignificant.

Figure 3 presents a summary of the relationship between social media platforms and content timings from the VT4 model. As seen in the table and figure, all the five social media platforms show a statistically significant association with the content timings variables. The strength of this association has been observed to be different by the Phi coefficient and Cramer's V coefficient which has shown that the degree of association for the social media platforms with content ties is not the same. The relationship represents a ranking of the media platforms in terms of how they contribute towards the content timings ranked in the order Facebook, Instagram, WhatsApp, WeChat and Twitter in the last position.

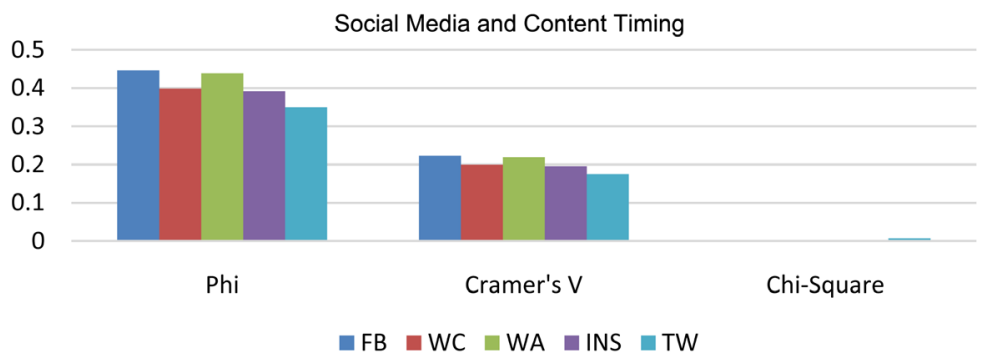

Figure 3. Relationship between Social media and content timing.

Table 6. Association between content ties and social media.

\begin{tabular}{|c|c|c|c|c|c|c|c|c|c|c|c|c|c|c|c|}
\hline \multirow{2}{*}{ Content Ties Variables } & \multicolumn{5}{|c|}{ Phi } & \multicolumn{5}{|c|}{ Cramer's V } & \multicolumn{5}{|c|}{ Pearson Chi-Square ( $p$-value) } \\
\hline & $\mathrm{FB}$ & WC & WA & INS & TW & $\mathrm{FB}$ & WC & WA & INS & TW & FB & WC & WA & INS & TW \\
\hline $\begin{array}{l}\text { My church has resources } \\
\text { to use social media }\end{array}$ & 0.457 & 0.370 & 0.519 & 0.401 & 0.448 & 0.229 & 0.185 & 0.260 & 0.201 & 0.224 & 0.000 & 0.000 & 0.000 & 0.000 & 0.000 \\
\hline $\begin{array}{l}\text { VIPs follow my church } \\
\text { on social media }\end{array}$ & 0.439 & 0.431 & 0.349 & 0.452 & 0.440 & 0.219 & 0.215 & 0.174 & 0.226 & 0.220 & 0.000 & 0.000 & 0.000 & 0.000 & 0.000 \\
\hline $\begin{array}{l}\text { My church uses multiple social } \\
\text { media platforms for each postng }\end{array}$ & 0.780 & 0.532 & 0.485 & 0.546 & 0.587 & 0.390 & 0.266 & 0.242 & 0.273 & 0.294 & 0.000 & 0.000 & 0.000 & 0.000 & 0.000 \\
\hline $\begin{array}{l}\text { My church always asks followers to like } \\
\text { and share its social media postings }\end{array}$ & 0.671 & 0.596 & 0.607 & 0.657 & 0.576 & 0.335 & 0.298 & 0.303 & 0.329 & 0.288 & 0.000 & 0.000 & 0.000 & 0.000 & 0.000 \\
\hline Averages & 0.587 & 0.482 & 0.490 & 0.514 & 0.513 & 0.293 & 0.241 & 0.245 & 0.257 & 0.257 & 0.000 & 0.000 & 0.000 & 0.000 & 0.000 \\
\hline
\end{tabular}




\section{Summary of Findings}

The data collected from church members as internal stakeholders was to determine the usefulness of social media in corporate reputation management. The first component was to determine how much volume of content about the organization's identity was being communicated and the response hereof from the said stakeholders. From data collected, there was an impressive degree of content volume communicated on social media. The next component looked at was data collected on the tone of the content created on social media. The response was that most of the time the organization was reluctant to offer an online apology whenever it was perceived to have erred and needless to say, it rarely responded whenever it was wrongly accused. From the third component's data collected it was also established that the organization's projection of its financial transparency on social media was not as impressive to its stakeholders. As much as it was established from the respondents' data collected that the organization had enough resources to establish a social media management system, the organization rarely communicated on multiple social network sites (SNS). This could be the explanation as to why the respondents felt the organization didn't have impressive ties with very important people who have great influence in the organization's brand establishment. The last component to be established was that WhatsApp as content ties was the most used and preferred communication channel.

\section{Conclusion}

The church has a very youthful membership, needless to emphasize that $67 \%$ of the respondents were up to the age of 30. This confirms that almost two-thirds of the organization's stakeholders belong to the screenagers generation. And since their gender, age, employment, and marital status had an influence on the degree of their social media activism, there remains a need for the organization to actively use social media in order to engage with these stakeholders. There are certain activities these stakeholders would appreciate seeing their organization use in order to communicate with them. There is less exploration in the usage of blogs, podcasting, and tweets from the organization as it communicates with its stakeholders. The content should resonate with the aspirations of the said stakeholders. This can be very effective if the organization's content is aligned with its aspirations. This can be very much effective if these stakeholders see the organization engage in corporate social responsibilities that resonate with their aspirations. Such activities have a tendency of managing the impressions of such stakeholders.

\section{Recommendation}

The organization must establish a social media communication system that must be manned by experts who will be able to effectively use the social media engagement tools. By establishing these tools, the personnel will be able to engage, 
track, monitor, and analyze conversations around the organization each time it is mentioned across social network sites. Needless to say, this will enable the publishing of the same content simultaneously across various channels. The organization should establish a dedicated page for Corporate Social Responsibility CSR activities, which should be updated so often, and always asking stakeholders to like and share the contents on their personal status or feed. Since Social media has turned employees into online brand ambassadors, or as organizational ambassadors in this context, it is the very urgent need for the organization to formulate and effectively implement a social media policy for its internal stakeholders. This will help manage both their public and private social engagements do not come into conflict with the organization's reputation.

\section{Future Research}

A study must be conducted on establishing the relationship between VT4 Model and Impression Management Theory especially when it comes to the tone of the content, there lays a gap in how impressions or perceptions can be strategically managed in order to achieve a positive response to a given content published.

\section{Limitation}

The Research was limited on the use of local literature covering this topic and the collection of questionnaires was wholly dependent on the local church leadership who were like research assistants and some took their time to do the task.

\section{Acknowledgements}

I would like to here thank my supervisor who kept encouraging me not to give up and putting in to this work countless hours. My first meeting with him was indeed divine providence. He has indeed broadened my academic focus.

\section{Conflicts of Interest}

The authors declare no conflicts of interest regarding the publication of this paper.

\section{References}

Abitbol, A., \& Lee, S. Y. (2017). Messages on CSR-Dedicated Facebook Pages: What Works and What Doesn't. Public Relations Review, 43, 796-808. https://doi.org/10.1016/j.pubrev.2017.05.002

Al-Alawi, A. I., Al-Marzooqi, N. Y., \& Fraidoon, M. (2007). Organizational Culture and Knowledge Sharing: Critical Success Factors. Journal of Knowledge Management, 11, 22-42. https://doi.org/10.1108/13673270710738898

Carroll, C. E., \& Deephouse, D. (2014). The Foundations of a Theory Explaining Organizational News: The VT4 Framework of Organizational News Content and Five Levels of Content Production. In J. Pallas, L. Strannegård, \& S. Jonsson (Eds.), Organizing in New Media Landscape (pp. 81-95). New York, NY: Routledge.

Deephouse, D. L., William, N., \& Abrahim, S. (2016). The Effects of Institutional Devel- 
opment and National Culture on Cross-National Differences in Corporate Reputation. Journal of World Business, 51, 463-473.

https://ideas.repec.org/a/eee/worbus/v51y2016i3p463-473.html https://doi.org/10.1016/j.jwb.2015.12.005

Fombrun, C. J., \& Van Riel, C. (2003). Fame and Fortune: How Successful Companies Build Winning Reputations (1st ed.). New York: Financial Times Prentice Hall.

Gilliam, B. (2007). Developing a Questionnaire. London: Sage Publication.

Hoegg, R., Robert, M., Meckel, M., \& Stanoevska-Slabeva, K. (2006). Overview of Business Models for Web 2.0 Communities. In M. Klaus, \& E. Martin (Eds.), Virtuelle Organisation und Neue Medien 2006 (pp. 33-50). Dresden: TUDpress.

Jones, B., Temperley, J., \& Lima, A. (2009). Corporate Reputation in the Era of Web 2.0: the Case of Primark. Journal of Marketing Management, 25, 927-939.

https://doi.org/10.1362/026725709X479309

Kane, G. C., Alavi, M., Labianca, G., \& Borgatti, S. P. (2014). What's Different about Social Media Networks? A Framework and Research Agenda. MIS Quarterly, 38, 275-304. https://doi.org/10.25300/MISQ/2014/38.1.13

Kang, M., \& Sung, M. (2017). How Symmetrical Employee Communication Leads to Employee Engagement and Positive Employee Communication Behaviors: The Mediation of Employee-Organization Relationships. Journal of Communication Management, 21, 82-102. https://doi.org/10.1108/JCOM-04-2016-0026

Kaplan, A. M., \& Haenlein, M. (2010). Users of the World, Unite! The Challenges and Opportunities of Social Media. Business Horizons, 53, 59-68. https://doi.org/10.1016/j.bushor.2009.09.003

Kaul, A., Chaudhri, V., Cherian, D., Freberg, K., Mishra, S., Kumar, R., Pridmore, J., Lee, S. Y., Rana, M., Majmudar, U., \& Carroll, C. E. (2015). Social Media: The New Mantra for Managing Reputation. Vikalpa, 40, 455-491.

https://doi.org/10.1177/0256090915618029

Kim, D. J., Yue, K. B., Hall, S. P., \& Gates, T. (2009). Global Diffusion of the Internet XV: Web 2.0 Technologies, Principles, and Applications: A Conceptual Framework from Technology Push and Demand Pull Perspective. Communications of the Association for Information Systems, 24, 657-678. https://doi.org/10.17705/1CAIS.02438

Kim, Y., \& Ferguson, M. A. (2019). Are High-Fit CSR Programs Always Better? The Effects of Corporate Reputation and CSR Fit on Stakeholder Responses. Corporate Communications: An International Journal, 24, 471-498. https://doi.org/10.1108/CCIJ-05-2018-0061

Madsen, V. T., \& Verhoeven, J. W. M. (2019). The Big Idea of Employees as Strategic Communicators in Public Relation. In Big Ideas in Public Relations Research and Practice (Advances in Public Relations and Communication Management) (Vol. 4, pp. 143-162). Bingley: Emerald Publishing Limited. https://doi.org/10.1108/S2398-391420190000004011

Marlene, L., Leal, C., \& Silva, R. (2017). Management of Internal Communication as a Strategic Tool for Employee Satisfaction. In Semetana, J., Rogers, M., \& Welfel, S. (Eds.), Organizational Culture and Leadership's Impact on a Safety Program Change Model (p. 626).

Marshall, G. (2005). The Purpose, Design and Administration of a Questionnaire for Data Collection, Radiography, 11, 131-136. https://www.sciencedirect.com/science/article/pii/S1078817404001208 https://doi.org/10.1016/j.radi.2004.09.002 
McCombs, M., \& Shaw, D. (1972). The Agenda-Setting Function of Mass Media. The Public Opinion Quarterly, 36, 176-187.

https://www.jstor.org/stable/2747787?seq=1 https://doi.org/10.1086/267990

Mousavi, N., Tajik, Z. M., \& Vahdati, H. (2015). The Study of Consumer Perception on Corporate Social Responsibility towards Consumers Attitude and Purchase Behavior, Asian Economic and Financial Review, 5, 831-845. https://doi.org/10.18488/journal.aefr/2015.5.5/102.5.831.845

O'Reilly, T. (2007). What Is Web 2.0: Design Patterns and Business Models for The Next Generation of Software. MPRA Paper, Germany: University Library of Munich.

Pallas, J., Strannegård, L., \& Jonsson, S. (2014). Organizations and the Media (1st ed.). London: Routledge. https://doi.org/10.4324/9780203068052

Pfarrer, M. D., Pollock, T. G., \& Rindova, V. P. (2010) A Tale of Two Assets: The Effects of Firm Reputation and Celebrity on Earnings Surprises and Investor's Reactions. Academy of Management Journal, 53, 1131-1152.

https://doi.org/10.5465/amj.2010.54533222

Shoemaker, P., \& Reese, S. (1996). Mediating the Message: Theories of Influence on Mass Media Content (2nd ed.). New York: Longman.

Van der Merwe, A., \& Puth, G. (2015). Towards a Conceptual Model of the Relationship between Corporate Trust and Corporate Reputation. Corporate Reputation Review, 17, 138-156. https://doi.org/10.1057/crr.2014.4

Waters, R. D., Burnett, E., Lamm, A., \& Lucas, J. (2009). Engaging Stakeholders through Social Networking: How Nonprofit Organizations Are Using Facebook. Public Relations Review, 35, 102-106. https://doi.org/10.1016/j.pubrev.2009.01.006 